\title{
СВІТОГЛЯДНІ ПРІОРИТЕТИ ГУМАНІЗАЦІЇ ВИЩОЇ ОСВІТИ В КОНТЕКСТІ ЗАБЕЗПЕЧЕННЯ ТА ВДОСКОНАЛЕННЯ ЯКОСТІ
}

Наукова доповідь Президії НАПН України 18 червня 2020 р. https://doi.org/10.37472/2707-305X-2020-2-1-2-7

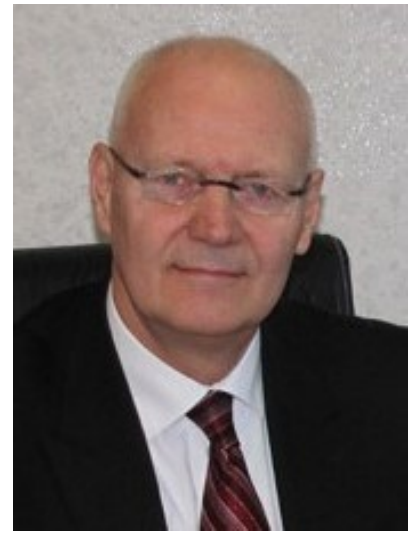

лУГОВИЙ Володимир Іларіонович

доктор педагогічних наук, професор, дійсний член (академік) НАПН України, перший віце-президент Національної академії педагогічних наук України, головний науковий співробітник відділу політики i врядування у вищій освіті Інституту вищої освіти Національної академії педагогічних наук України, м. Київ, Україна

\section{iD $\triangle$}

\section{ЗАГІРНЯК Михайло Васильович}

доктор технічних наук, професор, дійсний член (академік) НАПН України, член Президії НАПН України, ректор Кременчуцького начіонального університету імені Михайла Остроградського, м. Кременчук, Україна
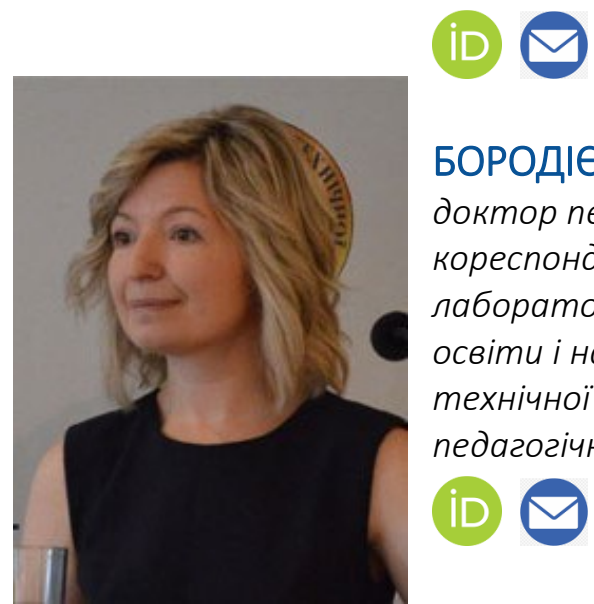

\section{БОРОДІЄНКО Олександра Володимирівна}

доктор педагогічних наук, дочент, членкореспондент НАПН України, завідувач лабораторії зарубінних систем професійної освіти і навчання Інституту профресійнотехнічної освіти Національної академії педагогічних наук України, м. Київ, Україна

\section{iD $\triangle$}

\section{АВШЕНЮК Наталія Миколаївна}

доктор педагогічних наук, старший науковий співробітник, завідувач відділу зарубіжних систем педагогічної освіти і освіти дорослих Інституту педагогічної освіти і освіти дорослих імені Івана Зязюна Національної академії педагогічних наук України, м. Київ, Україна

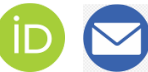

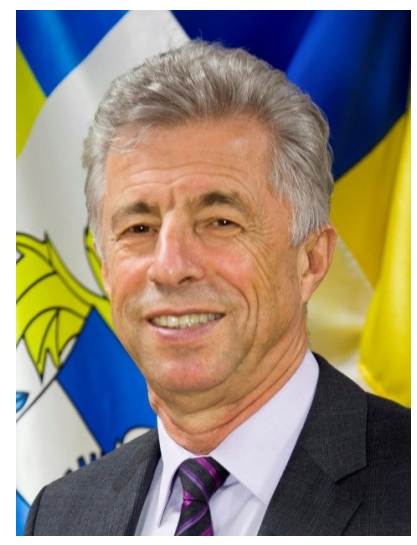

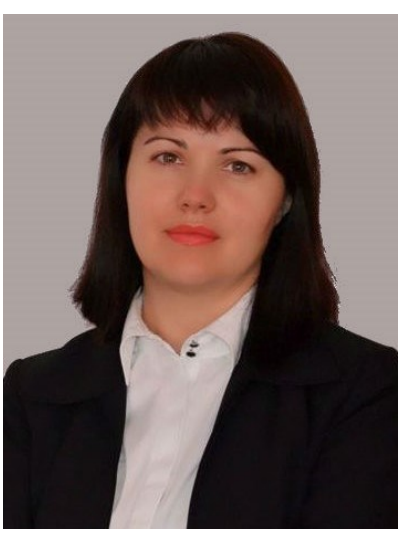


Анотація. Проаналізовано результати фундаментального наукового дослідження «Світоглядні пріоритети гуманізації вищої освіти», виконаного в Інституті вищої освіти Національної академії педагогічних наук України у 2015-2017 рр. 3'ясовано, що отримано вагомі, теоретично і практично значущі здобутки, зокрема розв'язано кілька фундаментальних задач, пов'язаних із гуманізацією вищої освіти. Визначено два ключових світоглядних пріоритети гуманізації вищої освіти - людиноцентризм (студентоцентризм) і якість. Обгрунтовано концептуальну модель гуманізації вищої освіти як засобу забезпечення освітньої якості в контексті європейської інтеграції і глобалізації.

Ключові слова: світоглядні пріоритети; гуманізація; вища освіта; людиноцентризм; якість.

Фундаментальне наукове дослідження «Світоглядні пріоритети гуманізації вищої освіти» виконувалося в Інституті вищої освіти Національної академії педагогічних наук України у 20152017 рр. Метою дослідження було визначено систематизацію і концептуалізацію світоглядних основ ефективної гуманізації вищої освіти. Основні завдання полягали в обґрунтуванні теоретичних основ гуманізації вищої освіти, аналізі провідного вітчизняного і зарубіжного досвіду та концептуальному моделюванні гуманізації вищої освіти як засобу забезпечення освітньої якості. За результатами дослідження отримано вагомі, теоретично і практично значущі здобутки, зокрема розв'язано кілька фундаментальних задач, пов'язаних з гуманізацією вищої освіти.

По-перше, обґрунтовано, що розгляд гуманізації з позицій ставлення до людини як найвищої цінності та всебічної підтримки її задатків і здібностей виявляє детермінуючу функцію гуманізації як імперативної вимоги забезпечення людиноцентризму і якості вищої освіти. На цій основі з'ясовано два ключових світоглядних пріоритети гуманізації вищої освіти - людиноцентризм (студентоцентризм) та якість. Це узгоджується 3 принципами побудови за Болонським процесом, до якого Україна приєдналася у 2005 р., привабливого і конкурентоспроможного Європейського простору вищої освіти.

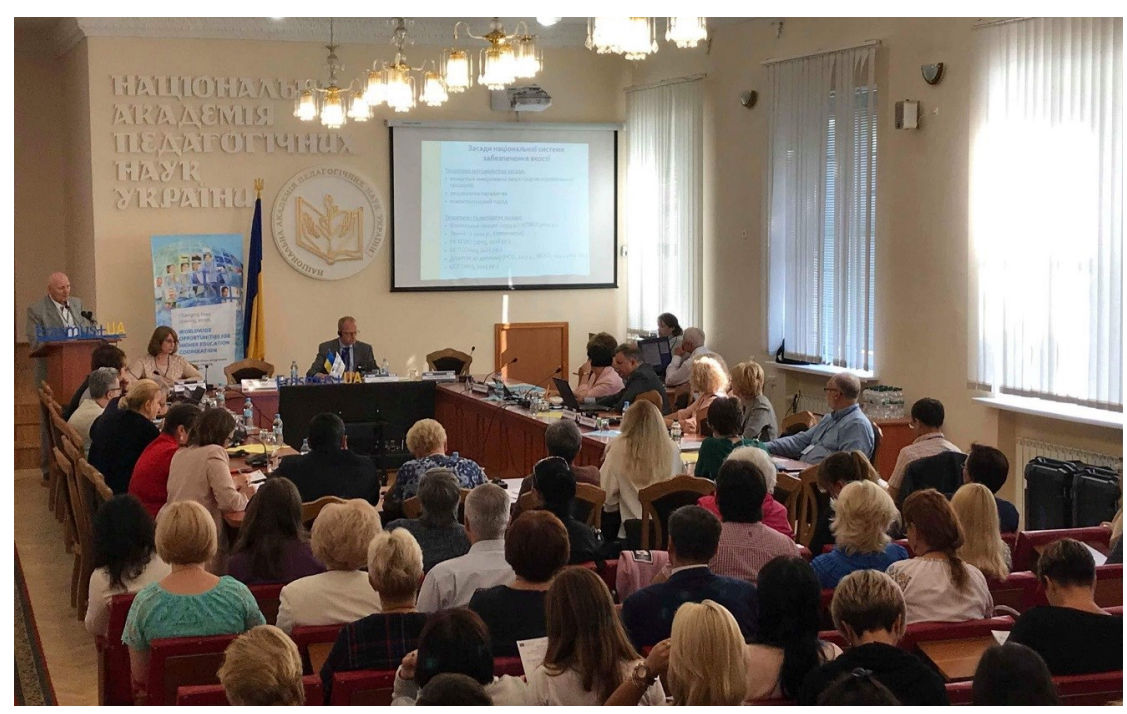

По-друге, зважаючи на вимогу людиноцентризму доведено теорему про існування канонічного (гранично мінімізованого) переліку основних компетентностей людини для ії успішної діяльності в сучасному світі. У результаті сформульовано закон базисної організації компетентностей (В.І. Луговий, О.М. Слюсаренко, Ж.В. Таланова). Він стверджує, що на найзагальнішому рівні теоретичного розгляду існує п'ять і тільки п'ять основних їх видів: інтелектуально-знаннєвий, творчо-інноваційний, ціннісно-орієнтаційний, діалого-консенсусний і художньо-творчий. Статус закону цьому теоретично доведеному твердженню надає його широкий діапазон застосування та емпіричне підтвердження (Воробйова та ін., 2017, c. 6-18).

По-mpemє, розкрито системну організацію якості, їі іманентну дихотомію, два принципово відмінних рівня існування: мінімально достатній і максимально досконалий. Якісний дуалізм (якістьвизначеність вищої освіти і якість-відповідність кращим очікуванням людини) зумовлює два підходи до досягнення якості - ії забезпечення (порогове убезпечення від неякості) та вдосконалення (підвищення до топових зразків), два види мотивації - зобов'язання виконання мінімуму і заохочення прагнення до максимуму, дві культури якості - мінімально необхідної та максимально конкурентної, два принципово різних механізми оцінювання якості - акредитаційний (оцінювання по-мінімуму) і рейтинговий (оцінювання по-максимуму). В основі мотивації заохочення досягнення досконалості - педагогічний закон зв'язку складності та самостійності в освіті, сформульований дослідниками (В.І. Луговий, Ж.В. Таланова) раніше (у 2013 р.) (Воробйова та ін., 2017, c. 87-90).

По-четверте, обґрунтовано концептуальну модель гуманізації вищої освіти як засобу забез- 


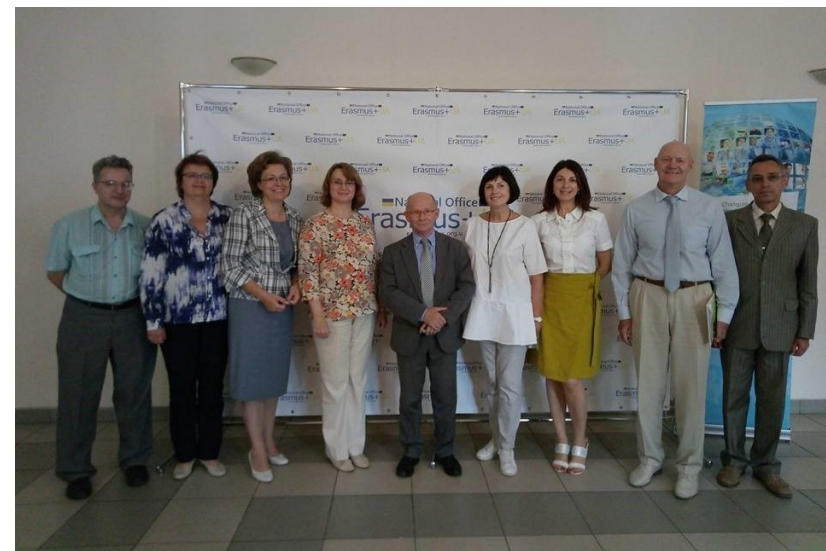

печення освітньої якості в контексті європейської інтеграції та глобалізації. Модель включає складники інтернаціоналізації вищої освіти, університетської автономії й інші механізми гуманізації вищої освіти з огляду на досягнення її людиноцентризму та якості.

Дослідження дало змогу частині його виконавців (В.І. Луговий, А.В. Ставицький та Ж.В. Таланова) взяти участь у створенні у 2016 р. на компетентнісній основі Методичних рекомендацій щодо розроблення стандартів вищої освіти (Воробйова та ін., 2016b; Методичні рекомендації, 2016; МОН України, 2016) і методично спрямовувати формування стандартів. у 20182020 рр. Міністерством освіти і науки України затверджено 142 стандарти вищої освіти бакалаврського і магістерського рівнів, з яких 138 (97\%) піддано методичній експертизі авторами дослідження (МОН України, n.d.).

Основні результати дослідження широко висвітлено в науковій продукції. Це, зокрема, аналітичні матеріали «Аналіз провідного вітчизняного та зарубіжного досвіду гуманізації вищої освіти як засобу забезпечення ії̈ якості», частина I (Бульвінська та ін., 2015) та частина II (Воробйова та ін, 2016а); методичні рекомендації «Гуманізація вищої освіти як засіб забезпечення ії якості в Україні» (Воробйова та ін., 2016b); монографія «Світоглядні пріоритети гуманізації вищої освіти» / за ред. В.І. Лугового, Ж.В. Таланової (Воробйова та ін., 2017). Загалом ці праці завантажувалися користувачами з Електронної бібліотеки НАПН України і сайту Інституту вищої освіти НАПН України 777 разів. Крім того, за темою дослідження опубліковано 80 статей у наукових фахових виданнях та 8 статей у зарубіжних виданнях. Результати дослідження дали підстави прогнозувати, що конкурентоспроможна якість буде й надалі орієнтиром для людиноцентрованого розвитку вищої освіти. На затребуваність дослід- ницьких результатів вказує також кількість цитувань та зростання у дослідників індексу Гірша та індексу і10 за Google Scholar Citations.

Упродовж 2016-2020 рр. здійснено апробацію, поширення і впровадження результатів дослідження на заходах в Україні і за кордоном, зокрема таких.

1.У робочих групах профільного Комітету Верховної Ради України та Міністерства освіти і науки України з розроблення проєкту Закону України «Про освіту» та внесення змін і доповнень до Закону України «Про вищу освіту». При створенні законодавства для формування на новій основі Національного агентства із забезпечення якості вищої освіти. На експертному круглому столі МОН України щодо проєкту Середньострокового плану пріоритетних дій Уряду до 2020 року за тематичним напрямом: забезпечення якості вищої освіти. У робочих групах міністерства з розроблення Концепції розвитку педагогічної освіти і супроводу Болонського процесу.

2. На заходах Національного Еразмус+ офісу в Україні та за проєктами міжнародної співпраці з Європейським Союзом, іншими міжнародними проєктами в Україні, Вірменії, Італії, Латвії, Литві, Сполученому Королівстві, Фінляндії, Франції, Чорногорії. На тренінгах для студентських експертів та для тренерів з підготовки експертів із забезпечення якості вищої освіти.

3. При розроблені та реалізації освітньонаукових програм «Політика і лідерство у вищій освіті», «Викладання і навчання у вищій освіті» в Інституті вищої освіти НАПН України, а також пропозицій із законодавчого забезпечення підготовки на освітньо-науковому і науковому рівнях для профільного Комітету Парламенту. У науковому керівництві і консультуванні підготовкою кандидатської (С.П. Шитікова) та докторської (М.А. Дебич) дисертацій.

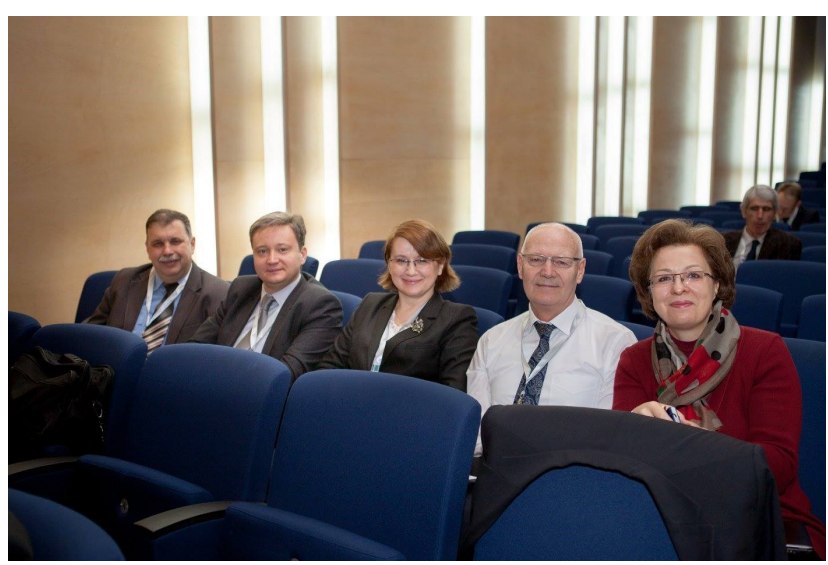


4. На методологічному семінарі НАПН України «Концептуальні засади розроблення Національного рейтингу закладів вищої освіти», на освітянських виставках. При підготовці україномовної та англомовної версій Національної доповіді про стан та перспективи розвитку освіти в Україні (Авшенюк та ін., 2016; Anishchenko et al., 2017), а також Національного освітньо-наукового глосарію (НАПН України, 2018) та рукопису другого видання Енциклопедії освіти. У збірнику Наукові розробки Національної академії педагогічних наук України, рекомендовані до впровадження (НАПН України, 2018). При складані та виконанні Програми спільної діяльності Міністерства освіти і науки України та Національної академії педагогічних наук України на 2017-2020 роки (НАПН України, 2017b) і Програми спільної діяльності Національної академії наук України та Національної академії педагогічних наук України на 20202022 роки (НАПН України, 2020). При розроблені і реалізації Стратегії розвитку НАПН України на 2016-2022 роки (НАПН України, 2016) та Пріоритетних напрямів (тематики) наукових досліджень на 2018-2022 рр. (НАПН України, 2017а) у НАПН України.

5. На заходах закладів вищої освіти і наукових установ Києва, а також університетів Глухова, Кременчука, Маріуполя, Сум, Чернігова, Ради ректорів Київського вузівського центру. В угодах про співпрацю Інституту вищої освіти НАПН України з рядом університетів. На звітних наукових конференціях установи.

Водночас досвід теоретичного і практичного використання отриманих результатів показав, що з метою підвищення його впливу в контексті «Відкритої науки» дослідницькому колективу необхідно активізувати публікації у фахових виданнях, що індексуються провідними міжнародними і національними наукометричними базами, зокрема Scopus i Web of Science Core Collec-

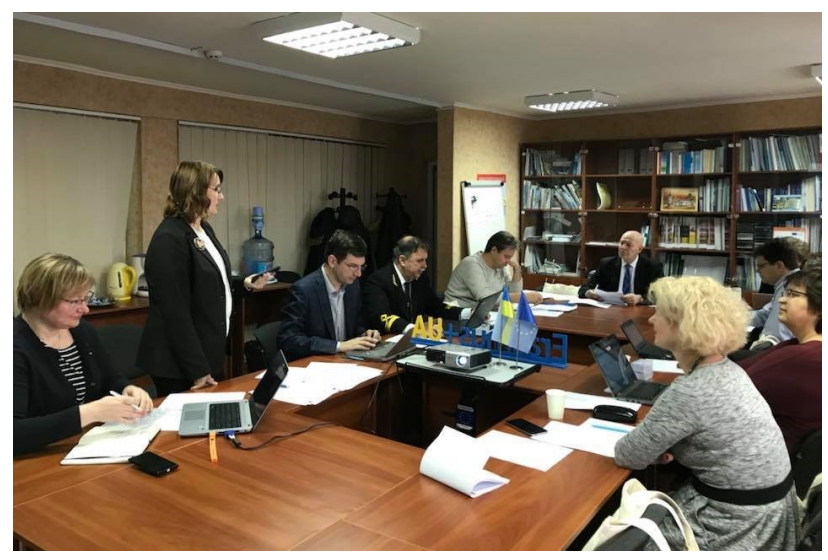

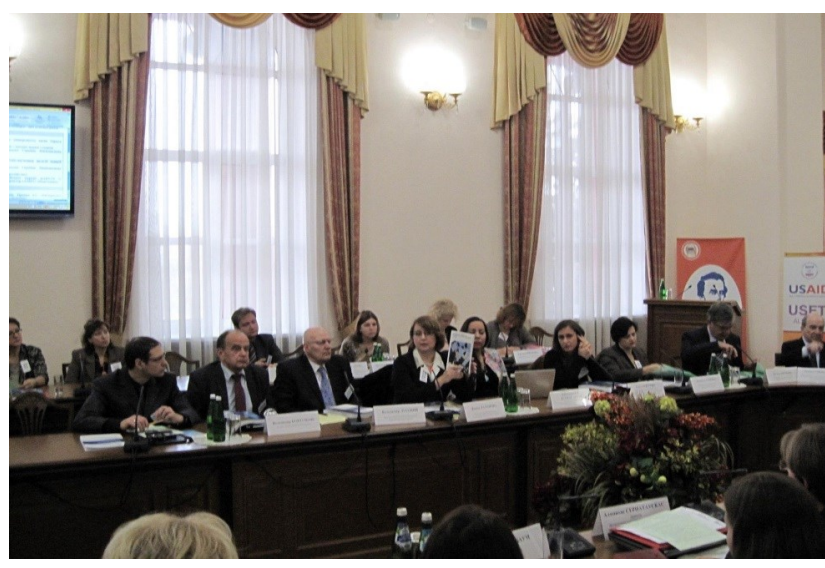

tion, а також англійською мовою та в електронних журналах і виданнях з високим імпакт-фактором.

Аналіз результатів дослідження «Світоглядні пріоритети гуманізації вищої освіти» та їх розгляд Президією НАПН України дають підстави для прийняття наступного рішення.

Перше. Позитивно оцінити інноваційні результати фундаментального наукового дослідження «Світоглядні пріоритети гуманізації вищої освіти», виконаного у 2015-2017 рр., та його теоретичний і практичний вплив на системну модернізацію вищої освіти в Україні. Вважати доцільним широко використовувати в дослідницькій і освітянській діяльності праці за цією тематикою, що оприлюднені в Електронній бібліотеці НАПН України та на веб-сайті Інституту вищої освіти НАПН України.

Друге. Рекомендувати академікам-секретарям відділень, керівникам підвідомчих установ:

- вважати пріоритетною тематику гуманізації освіти на засадах людиноцентризму та забезпечення і вдосконалення освітньої якості;

- з метою підвищення ефективності і повноти використання наукових результатів, їх європейського та світового поширення в контексті «Відкритої науки» активізувати публікації у фахових виданнях, що індексуються у провідних міжнародних і національних наукометричних базах, зокрема Scopus та Web of Science Core Collection, а також англійською мовою та в електронних журналах і виданнях з високим імпакт-фактором;

- при плануванні та реалізації пріоритетної тематики наукових досліджень у НАПН України забезпечити ії наступність, актуальність, відповідність пріоритетам і першочерговим завданням державної освітньої політики, суспільним запитам;

- забезпечити повне виконання відповідних заходів Програми спільної діяльності Міністерства освіти і науки України та Національної академії педагогічних наук України на 2017-2020 роки і 


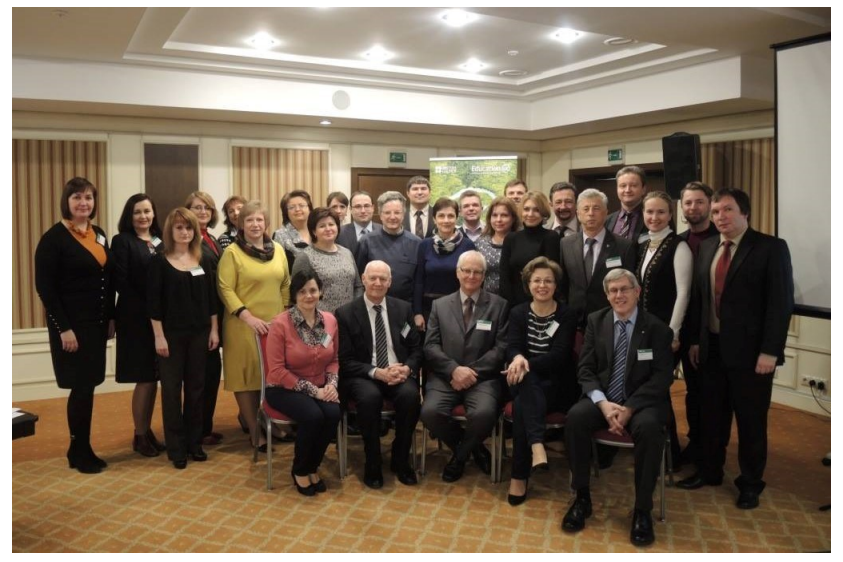

Програми спільної діяльності Національної академії наук України та Національної академії педагогічних наук України на 2020-2022 роки;

- у дослідницькій діяльності використовувати можливості проєктного фінансування міжнародними організаціями та Національним фондом досліджень України, зокрема з метою підтримки молодих вчених.

Tретє. Доручити Інституту вищої освіти НАПН України (С.А. Калашнікова), керівнику наукового дослідження «Механізми оцінювання якості вищої освіти в умовах євроінтеграції» (В.І. Луговий), що виконується у 2018-2020 рр., спрямувати колектив дослідників на теоретичне обґрунтування і методичні рекомендації щодо розв'язання таких актуальних для України проблем:

- створення національної системи оцінювання якості вищої освіти із врахуванням кращих вітчизняних і зарубіжних практик;

- використання механізмів оцінювання якості вищої освіти для точного і надійного визначення в Україні профілів якості вищої освіти;

- ідентифікації не тільки закладів з мінімально достатньою якістю вищої освіти, а й осередків вищої освіти найвищої досконалості, центрів конкурентоспроможного зростання;

- обґрунтування запровадження певних цільових показників діяльності (результативності, ефективності та якості) закладу вищої освіти і механізму їх визначення для конкретного закладу та погодження із зацікавленими сторонами.

Четверте. Покласти на академіків-секретарів відділень контроль за виконанням постанови Президії НАПН України.

Відповідна ухвала Президії НАПН України сприятиме науковому і методичному забезпеченню модернізації вищої освіти в Україні, системному обґрунтуванню стратегії досягнення університетської конкурентоспроможності.

\section{СПИСОК ВИКОРИСТАНИХ ДЖЕРЕЛ}

Авшенюк, Н.М., Аніщенко, О.В., Артюшина, М.В., Балл, Г.О., Березівська, Л.Д., Бех, І.Д., Биков, В.Ю., Бібік, Н.М., Бородієнко, О.В., Бурда, М.І., Васьківська, Г.О., Вашуленко, О.П., Вітренко, Ю.М., Вовк, М.П., Вовченко, О.А., Волярська, О.С., Ворона, В.О., Горностай, П.П., Гудим, І.М., ... Шкільна, І.М. (2016). Національна доповідь про стан і перспективи розвитку освіти в Україні (В.Г. Кремень, ред.). Національна академія педагогічних наук України. Київ: Педагогічна думка. https://lib.iitta.gov.ua/166230/ Бульвінська, О.І., Гриценко, М.В., Рябченко, В.І., Самчук, З.Ф., \& Червона, Л.М. (2015). Аналіз провідного вітчизняного та зарубінного досвіду гуманізації вищої освіти як засобу забезпечення ї̈ якості (частина I) : препринт (аналітичні матеріали) (3.Ф. Самчук, М.В. Гриценко, ред.). Київ: ІВО НАПН України. https://bit.ly/38w5s6B

Воробйова, О., Гриценко, М., Луговий, В., Слюсаренко, О., Ставицький, А., Таланова, Ж., \& Ткаченко, В. (2016а). Аналіз провідного вітчизняного та зарубіжного досвіду гуманізаиії вищої освіти як засобу забезпечення ї̈ якості (частина II) : аналітичні матеріали (В. Луговий, Ж. Таланова, ред.). Київ: ІBO НАПН України. https://bit.ly/2ZKgwcx

Воробйова, О., Гриценко, М., Луговий, В., Слюсаренко, О., Ставицький, А., Таланова, Ж., \& Ткаченко, В. (2016b). Гуманізація вищої освіти як засіб забезпечення ії якості в Україні : методичні рекомендації (В. Луговий, Ж. Таланова, ред.). Київ: ІВО НАПН України. https://bit.ly/2018eat

Воробйова, О.П., Гриценко, М.В., Луговий, В.І., Оржель, О.Ю., Слюсаренко, О.М., Ставицький, А.В., Таланова, Ж.В., Ткаченко, В.П., \& Трима, К.А. (2017). Світоглядні пріоритети гуманізації вищої освіти : монографія (В.І. Луговий, Ж.В. Таланова, ред.). Київ: IBO НАПН України.https://bit.ly/2ZAPRPa

Методичні рекомендації щодо розроблення стандартів вищої освіти. (2016). Схвалено сектором вищої освіти Науково-методичної Ради Міністерства освіти і науки України протокол від 29.03.2016 № 3 . https://www.univer.kharkov.ua/docs/work/metodmon.pdf

Міністерство освіти і науки України. (2016, 1 червня). Про затвердження та введення в дію Методич них рекомендацій щодо розроблення стандартів вищої освіти (600). https://mon.gov.ua/ua/npa/prozatverdzhennya-ta-vvedennya-v-diyu-metodichnikhrekomendatsiy-shchodo-rozroblennya-standartivvishchoi-osviti

Міністерство освіти і науки України. (n.d.). Затверджені стандарти вищої освіти. https://mon.gov.ua/ ua/osvita/visha-osvita/naukovo-metodichna-radaministerstva-osviti-i-nauki-ukrayini/zatverdzhenistandarti-vishoyi-osviti

Наукові розробки Начіональної академії педагогічних наук України, рекомендовані до впровадження : Збірник анотованого переліку наукових розробок. (2018). Київ: НАПН України. https://bit.ly/3e453t6

Національна академія педагогічних наук України. (2016). Стратегія розвитку Національної академії педагогічних наук України на 2016-2022 роки. http://naps.gov.ua/ua/press/announcements/942/ 
Національна академія педагогічних наук України. (2017а). Пріоритетні напрями (тематика) наукових досліджень та науково-технічних (експериментальних) розробок Національної академіі педагогічних наук України на 2018-2022 рp. http:// naps.gov.ua/ua/press/announcements/1315/

Національна академія педагогічних наук України. (2017b). Програма спільної діяльності Міністерства освіти і науки України та Національної академії педагогічних наук України на 2017-2020 роки. http://naps.gov.ua/ua/activities/research/mon/

Національна академія педагогічних наук України. (2018). Національний освітньо-науковий глосарій. Київ: ТОВ «КОНВІ ПРІНТ». https://lib.iitta.gov.ua/715512/
Національна академія педагогічних наук України. (2020). Програма спільної діяльності Національної академії наук України та Національної академії педагогічних наук України на 2020-2022 роки. http://naps.gov.ua/ua/activities/research/nas/

Anishchenko, O.V., Artiushyna, M.V., Avsheniuk, N.M., Ball, G.O., Bazeliuk, N.V., Bekh, I.D., Berezivska, L.D., Bibik, N.M., Borodiienko, O.V., Burda, M.I., Bykov, V.Yu., Chorna, L.G., Dorotiuk, V.I., Dovbyshchenko, V.I., Dzhurylo, A.P., Dziubko, L.V., Gurzhii, A.M., Hornostai, P.P., Hudym, I.M., ... Zozulia, S.M. (2017). National Report on the State and Prospects of Education Development in Ukraine (V.G. Kremen, Ed.) National Academy of Educational Sciences of Ukraine. Kyiv: Pedahohichna dumka. https://lib.iitta.gov.ua/706242/

\section{WORLDVIEW PRIORITIES FOR HIGHER EDUCATION HUMANISATION \\ IN THE CONTEXT OF QUALITY ASSURANCE AND IMPROVEMENT \\ Scientific Report to the Presidium of the National Academy of \\ Educational Sciences of Ukraine, June, 18, 2020}

Volodymyr Lugovyi

DSC in Education, Professor, Full Member (Academician) of NAES of Ukraine, First Vice-President, National Academy of Educational Sciences of Ukraine; Chief Research Fellow of the Department for Policy and Governance in Higher

Education, Institute of Higher Education of the National Academy of Educational Sciences of Ukraine, Kyiv, Ukraine Mykhaylo Zagirnyak

DSc in Engineering, Professor, Full Member (Academician) of NAES of Ukraine, Member of the Presidium of NAES of Ukraine, Rector, Kremenchuk Mykhailo Ostohradskyi National University, Kremenchuk, Ukraine Oleksandra Borodiienko

DSc in Pedagogy, Associate Professor, Corresponding Member of NAES of Ukraine, Head of the Foreign Vocational Education and Training Systems Laboratory, Institute of Vocational Education and Training the National Academy of Educational Sciences of Ukraine, Kyiv, Ukraine Natalia Avshenyuk

DSc in Pedagogy, Senior Researcher, Head of the Foreign Pedagogical Systems and Adult Education Department, Ivan Ziaziun Institute of Pedagogical and Adult Education of the National Academy of Educational Sciences of Ukraine, Kyiv, Ukraine

Abstract. The results of the basic research "The Worldview Priorities of Higher Education Humanisation", which was carried out in the Institute of Higher Education of the National Academy of Educational Sciences of Ukraine in 20152017, are analysed. It was found that the substantial, theoretically and practically significant achievements have been received, in particular several basic problems related to higher education humanisation have been solved. Two key worldview priorities of higher education humanisation have been defined, i.e. human-centrism (student-centrism) and quality. The conceptual model of higher education humanisation as a tool for education quality assurance in the context of European integration and globalisation has been grounded.

Keywords: worldview priorities; humanisation; higher education; human-centrism; quality.

Дата публікації: 30 червня 2020 p. 